\section{Technical Association News}

\section{ALBERTA}

\section{President's Report}

Several months have passed since our AGM in March and a few things have been happening within AFTA

We have finalized our lease agreement and moved into our new office space with the ARPFA on May 9th. This is a new chapter in the development of our association. We have existed in a one-room office at the CFS building for some years and now have two full-time staff and require an office and infrastructure to serve an association of $400+$ members. Our location at the Northern Forestry Centre no longer sufficed and so we moved into a $1200-\mathrm{ft}^{2}$ office at 209 10544 106th Street in Edmonton.

The AFTA office was closed for a few days around the 9th to accommodate the move, but is now open for business.

Your council met recently to discuss the draft regulations and strategize the com-

AFTA/ARPFA has moved. Our new location is on the downtown fringe near Grant MacEwen College.

Our new address is: 209, 10544-106 Street Edmonton, Alberta T5H 2 X6 munication of these regulations to our membership and stakeholders. We will be putting together, with the ARPFA, a communication plan that outlines this strategy. Please provide any comments or suggestions to Kathleen Doerkson, Communications Director, about how you think we should "get the message out."

Your association needs you. Your council has identified a need to strike several committees to meet the requirements of the regulations and growing needs of an association our size. If you are interested in helping out please contact Frankie Kerr or me and we will put you in touch with the right person. The committees that require help are: Complaints, Competency, Exam, Awards, Nomination, CFE, Legislative, Membership, and Communications.

Since our AGM in March when our membership totaled 316, we have increased our membership to approximately 400 people. We are drawing closer to our budget projection of 439 memberships.

I'm always interested in what you have to say so give me a call at 780-7782221 ext 2104 or e-mail me at rhilts@millarwestern.com.

\section{Ray Hilts}

From ForTech Alberta Forest Technologists Newsletter

\section{SPECIAL SubsCRIPTION Prices for CIF/IFC MeMbers!}

Canadian Journal of Forest Research Subscription Rate for 2002

Member In Canada

Printed Version Only

Electronic Version Only

In Canada

$\$ 92.00$ (plus $\$ 6.44$ GST) $=\$ 98.44$

Free

\author{
Member Outside Canada \\ Printed \\ Electronic Version Only \\ Printed + Electronic
}

All Members outside Canada please add $\$ 60.00$ postage

Environmental Reviews Quarterly Rate for 2002

Member In Canada

Printed Version Only

Electronic Version Only

In Canada

$\$ 38.00$ (plus $\$ 2.66$ GST) $=\$ 40.66$

Member Outside Canada

Printed

Free

Electronic Version Only

Printed + Electronic

All Members outside Canada please add $\$ 20.00$ postage

\section{TREEVIA QUIZ}

1. How do coniferous trees bear their seeds?

2. Do evergreens ever drop their needles?

3. Explain why the larch, or tamarack, is a unique coniferous tree.

4. How do trees "drink" water?

5. The process by which trees give off water vapour through their leaves is called:

a) transpiration b) respiration c) photosynthesis.

6. Trees give off excess water through microscopic

holes in the leaves called:

a) the palisade layer b) the epidermis c) the stomata.

7. How does Alberta's forestry sector contribute to the economy of the province?

8. Which of the following is B.C.'s most harvested tree species?

a) Douglas-fir b) Lodgepole pine c) Western hemlock 9. Name one of the two hardwood species, formerly considered "weed trees," that have recently become commercially important in Alberta.

10. Forest fires destroy more forested area than are harvested each year.

True or false?

11. Many forest fires are caused by lightning. How often does lightning strike the earth's surface every second?

a) 50 b) 100 c) 200

12. In 1825 , a large forest fire destroyed over 15000 square kilometres along what New Brunswick river?

13. In recent years, forest managers have begun controlling forest insect infestations with bacteria.

True of false?

14. Which bird species is considered a minor forest pest? 15. Identify one technique used by scientists to predict the severity of next year's insect infestation.

a) Doing an anlysis of previous outbreaks.

b) Counting overwintering insect egg masses.

c) Adding $20 \%$ to last year's figures.

uonejsogut $\mathrm{s}_{\text {.reว }}$

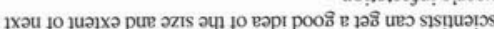

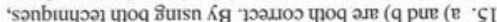

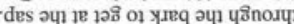

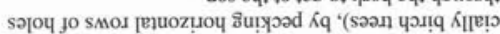

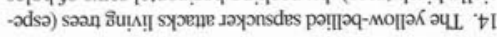

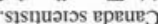

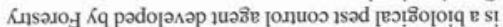

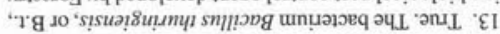

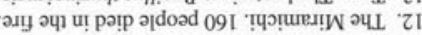

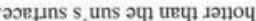

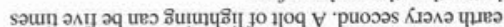

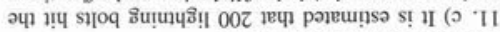
paisan.re are sarejəy 000006

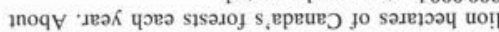

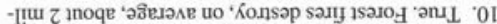

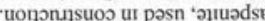

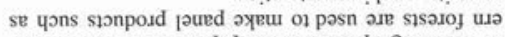

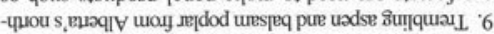

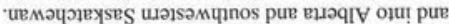

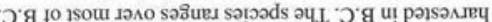

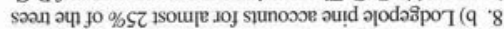

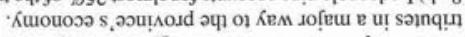

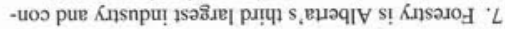

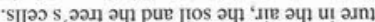

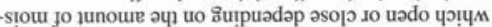

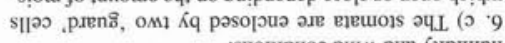
suoṇ!̣puos pu!̣m pue Kị̣p!̣uny

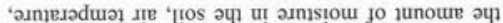

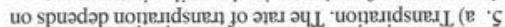

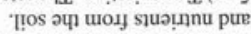

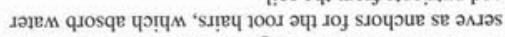

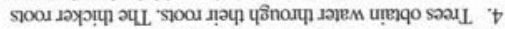

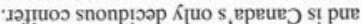

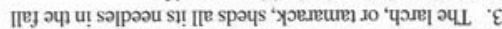

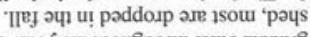

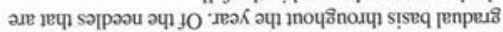

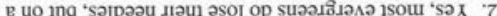

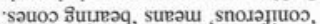

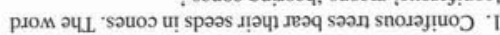
:S\&AMSNV 